\title{
Alagille syndrome: Resolution of xanthomas
}

\author{
NJ LEONARD MD, V DIAS PHD, HG PARSONS MD
}

\begin{abstract}
NJ LeONARD, V Dias, HG PARSONS. Alagille syndrome: Resolution of xanthomas. Can J Gastroenterol 1995;9(4):187-190. Alagille syndrome is a rare autosomal dominant disorder characterized by chronic cholestasis due to paucity of intrahepatic biliary ducts, characteristic facies, peripheral pulmonary stenosis, ocular posterior embryotoxon and skeletal abnormalities. Very little information is available on the cholestatic, lipid and lipoprotein profiles in individuals with Alagille syndrome. The course of xanthomatosis and the lipid-lipoprotein profile of a 15 -year-old male with incomplete Alagille syndrome with marked xanthomatosis and extremely elevated cholesterols secondary to cholestasis is reported. He showed gradual resolution of xanthomas beginning at age 12 years with a concurrent reduction in his total serum cholesterol. The lipid studies showed that the majority of cholesterol was found in low density lipoprotein (LDL) with lesser amounts in lipoprotein (Lp)-X, a lipoprotein precursor complex seen in patients with cholestasis, and high density lipoprotein (HDL). With resolution of xanthomas, LDL and Lp-X decreased while HDL-cholesterol and apolipoprotein (Apo) A-I increased. Gamma glutamyltransferase and bilirubin decreased but remained 15 - and threefold elevated, respectively.
\end{abstract}

Key Words: Alagille syndrome, Cholesterol, Cholestyramine, Intrahepatic cholestasis, Lipoprotein X, Xanthoma

\section{Syndrome d'Alagille : résolution de xanthomes}

RÉSUMÉ : Le syndrome d'Alagille est une maladie rare à caractère autosomique dominant caractérisée par une choléstase chronique attribuable à la piètre perméabilité des voies biliaires intrahépatiques, par un faciès typique, une sténose pulmonaire périphérique, un embryotoxon postérieur et des anomalies du squelette. Très peu de renseignements sont disponibles sur les profils choléstatiques, lipidiques et lipoprotéiques des sujets atteints du syndrome d'Alagille. L'évolution de la xanthomatose et le profil des lipides et des lipoprotéines d'un garçon de 15 ans atteint d'un syndrome d'Alagille partiel avec xanthomatose marquée et cholestérol extrêmement élevé secondaire à la choléstase sont présentés ici. Le patient a manifesté une résolution graduelle de ses xanthomes vers l'âge de 12 ans, avec réduction concurrente de son cholestérol sérique total.

voir page suivante

Department of Genetics, Department of Pediatrics, Alberta Children's Hospital; and Faculty of Medicine, University of Calgary, Calgary, Alberta

Correspondence and reprints: Dr Howard G Parsons, University of Calgary, Health Sciences Centre, 3330 Hospital Drive NW, Calgary, Alberta T2N 4N1. Telephone 403-220-7496,

Fax 403-283-3028, e-mail hparsons@acs.ucalgary.ca

Received for publication October 15, 1993. Accepted November 21, 1994
A LAGILLE SYNDROME (ARTERIOHEpatic dysplasia) is an autosomal dominant disorder characterized by chronic cholestasis due to a paucity of intrahepatic bile ducts, characteristic facies, peripheral pulmonary artery stenosis, skeletal abnormalities and ocular posterior embryotoxon (1). Individuals with Alagille syndrome must have two or more of these features (2). The paucity of intrahepatic bile ducts results in a variable degree of chronic cholestasis with elevation of liver enzymes, plasma phospholipids and cholesterol. A case of a 15-year-old male with Alagille syndrome who developed xanthomatosis by age two years with resolution beginning at age 12 years is reported. As little information is available on the resolution of xanthomas and on lipids and lipoprotein profiles in individuals with Alagille syndrome, serum cholesterol, low density lipoprotein (LDL), high density lipoprotein (HDL) and lipoprotein (Lp)-X were assessed in this patient. Lp-X is a low density precursor lipoprotein that is normally excreted in bile but is present in the circulatory system under cholestatic condition (3-6).

\section{CASE PRESENTATION}

The patient was a 15 -year-old Caucasian male. The perinatal course was unremarkable. He was born at term, birth weight $2.7 \mathrm{~kg}(10 \%)$, and had 'mild jaundice' that did not require treatment. He was discharged home on day 3 of life and had difficulties, with poor feeding irritability and increased 
Les examens lipidiques ont révélé que la majeure partie du cholestérol se trouvait sous forme de lipoprotéines de basse densité, avec des quantités moindres de lipoprotéines ( $\mathrm{Lp}-\mathrm{X})$, complexe précurseur des lipoprotéines qui s'observe chez les patients atteints de choléstase et de lipoprotéines de haute densité. Avec la résolution des xanthomes, les LDL et les Lp-X ont diminué, alors que le HDL-cholestérol et l'apolipoprotéine (Apo A-1) ont augmenté. La gamma glutamyltransférase et la bilirubine ont diminué, mais sont demeurées respectivement 15 fois et 3 fois plus élevées.

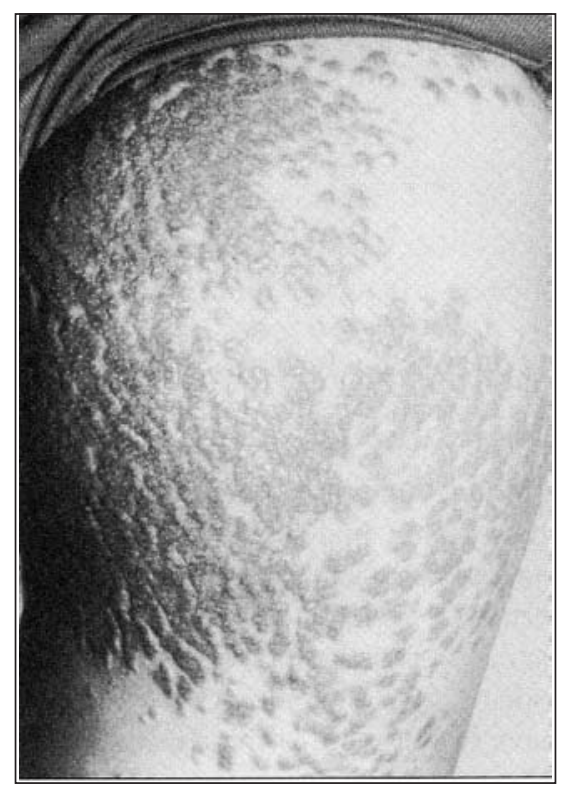

Figure 1) Photograph of buttock covered with xanthomas at age 12 years

jaundice. At three months of age he was found to have bleeding from his right ear, increased jaundice and loose fatty stools. Investigations revealed a three- to fourfold elevation in aspartate aminotransferase and alanine aminotransferase (ALT), a 20 - to 30-fold elevation in gamma glutamyltransferase (GGT) and a three- to fourfold elevation in total bilirubin ( 60 to $80 \%$ conjugated) reflecting an obstructive picture. Liver biopsies at three and nine months showed cholestasis but were inconclusive for Alagille syndrome.

When the patient was five years old a repeat liver biopsy showed the characteristic paucity of intrahepatic bile ducts that is seen in Alagille syndrome. Additional features included the characteristic facies of Alagille syndrome with prominent forehead, deep set eyes, hypertelorism, straight nose and small pointed chin. He had a III/VI systolic murmur and a widely split S2 diagnosed as peripheral pulmonary artery

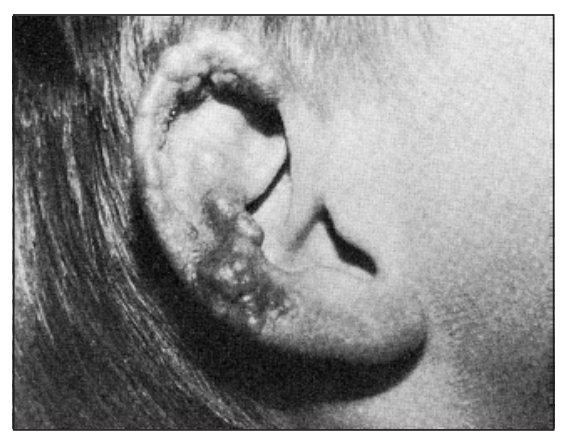

Figure 2A) Photograph of right ear showing marked xanthomas at age 12 years

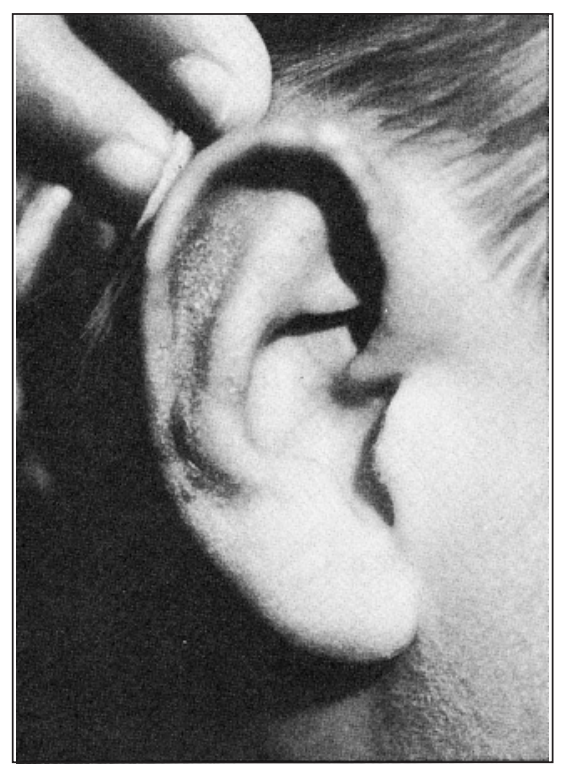

Figure 2B) Photograph of right ear showing subsequent resolution of xanthomas by age 15 years

stenosis by echocardiogram. Ophthalmic examination showed no posterior embryotoxon and skeletal surveys at age two and 15 years were normal.

$\mathrm{He}$ developed problems with xanthomatosis and pruritus around age two years. The xanthomas began on the flexor surface of his forearms and gradually increased in size and spread to the extensor surfaces. By age 12 years he had extensive red-brown xanthomas covering most of the extensor surfaces of his arms, the dorsal aspect of his hands, the anterior and posterior aspects of his thighs, and the posterior aspect of his buttocks and lower back (Figure 1). He had extensive xanthomas on the helices and the posterior aspect of the ears (Figure 2) and small lesions on the buccal mucosa. He had bilateral arcus adiposus and fundoscopic findings of silver wiring, and small tortuous arteries and veins. Exercise tolerance testing and coronary arteries on echocardiogram were normal at age 12 years. Neurological examination and development were normal and he had honours standing in school. At age 15 years he had Tanner II development. Renal function, ultrasound of the liver and alpha-fetoprotein were normal at age 15 years. Chromosome studies were normal with no evidence of a deletion on the short arm of chromosome 20 (20p). Small deletions of $20 \mathrm{p}$ can be seen in some individuals with Alagille syndrome.

There was no family history of Alagille syndrome. His parents had normal lipid profiles, and clinical examination showed no evidence of Alagille syndrome. The patient was treated with supplemental vitamins and cholestyramine for pruritus on an intermittent basis before age 10 years. At age 12 years, while undergoing investigations for elevated cholesterol and xanthomas, the patient was placed on a high soluble fibre diet with 30\% fat, $140 \mathrm{mg} /$ day cholesterol, $20 \%$ protein and $50 \%$ carbohydrates. At age 12.5 years he was started on cholestyramine $4 \mathrm{~g}$ bid on a regular basis.

\section{METHODS}

Blood samples were drawn after a $12 \mathrm{~h}$ fast. HDL cholesterol was assayed after precipitation of LDL and very low density lipoprotein (VLDL) by sodium phosphotungstate- $\mathrm{Mg}^{++}$(7). Serum apolipoprotein (apo) A-I and apoB were determined by single radial immunodiffusion (Tago Diffu-Gen apoA or apoB, California) (8). Lp-X was quantitatively determined by the method of Panteghini and colleagues (9). Phospholipids were fractionated chroma- 


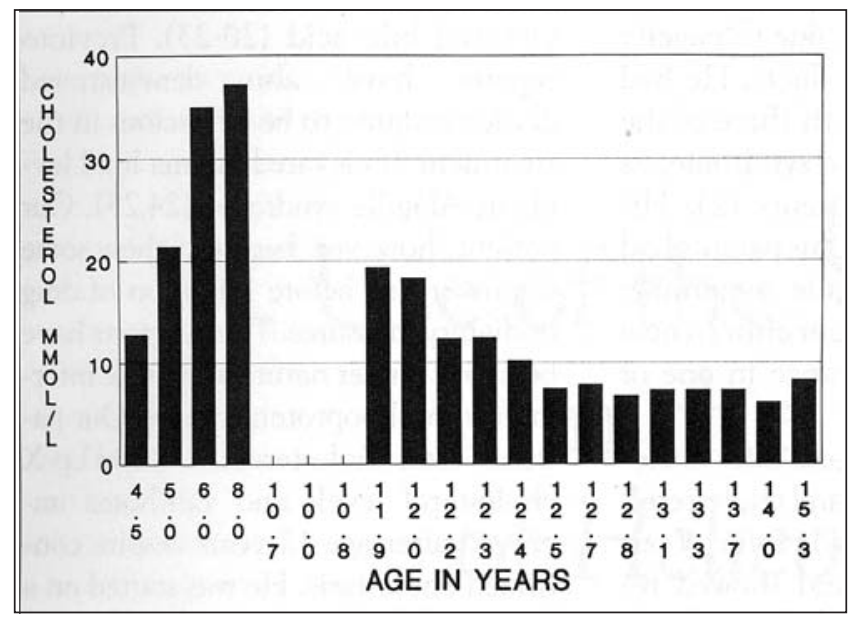

Figure 3) Total plasma cholesterol by age in years. Diet therapy began at age 12.2 years and cholestyramine therapy at 12.5 years. The upper normal level for total cholesterol in male children is $4.9 \mathrm{mmol} / \mathrm{L}$

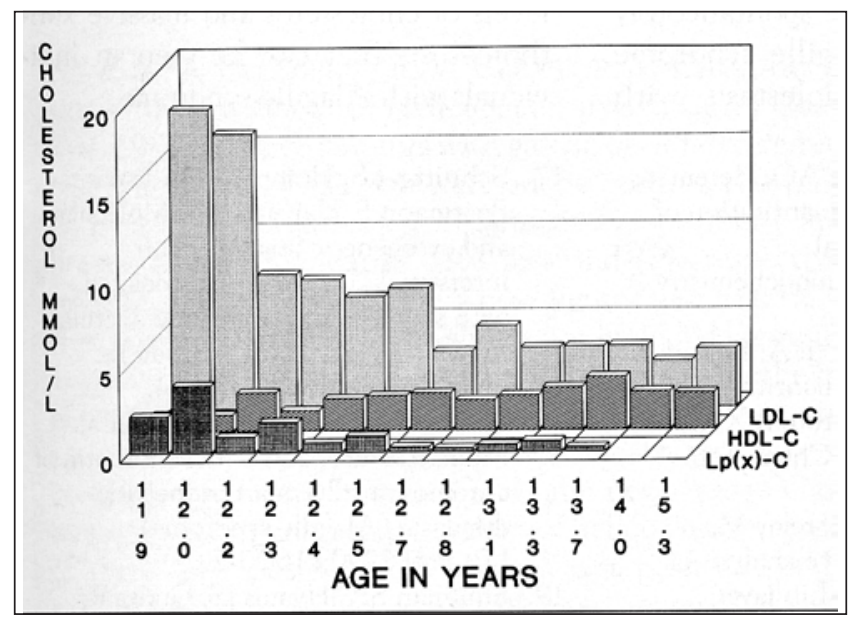

Figure 4) Low density lipoprotein (LDL), high density lipoprotein $(\mathrm{HDL})$ and lipoprotein $\mathrm{X}(\mathrm{Lp}-\mathrm{X})$ cholesterol at different ages

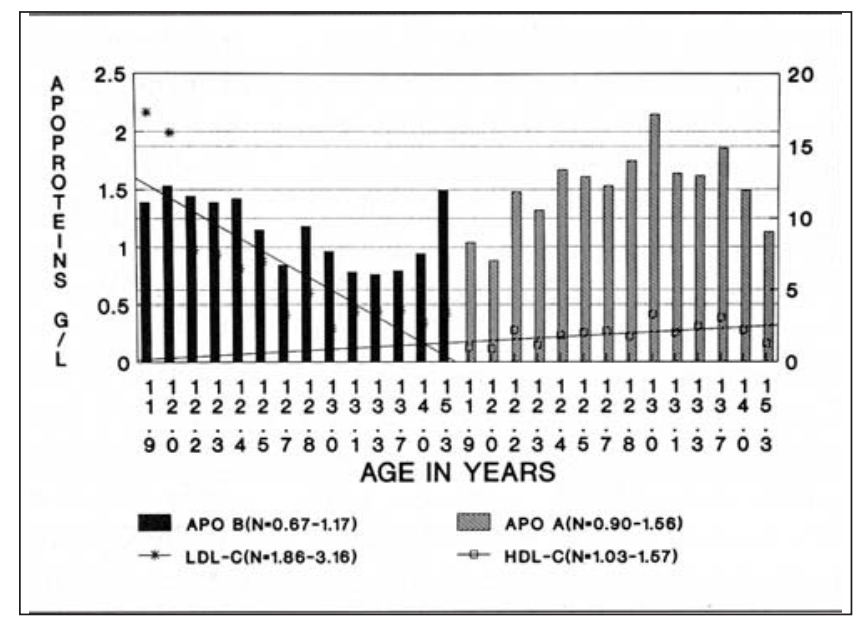

Figure 5) Lipoprotein A-I and B levels at different ages. APO A Apolipoprotein A; APO B Apolipoprotein B; HDL High density lipoprotein; LDL Low density lipoprotein

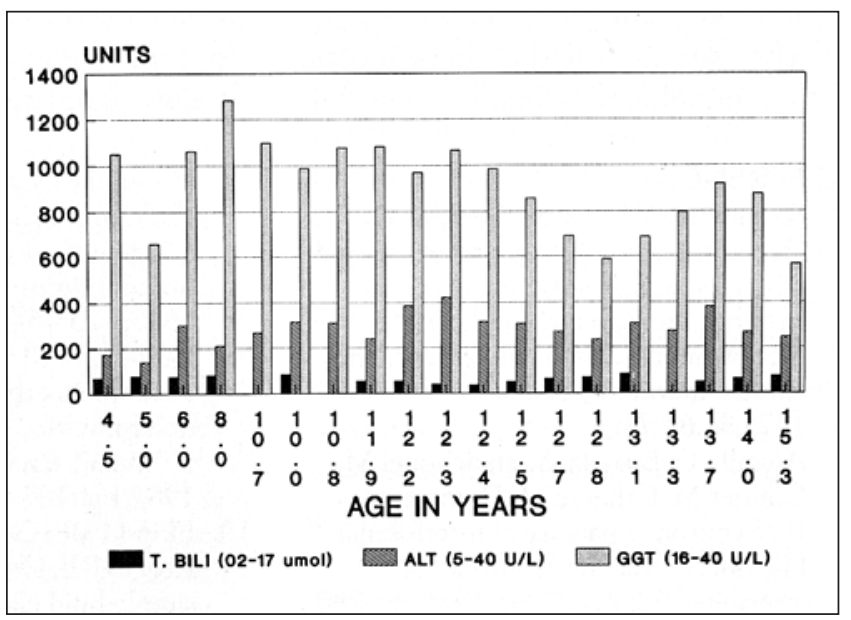

Figure 6) Liver enzymes of total bilirubin (T BILI), alanine aminotransferase (ALT) and gamma glutamyltransferase (GGT) at different ages

tographically (10) and quantified by the method of Bartlett (11). High resolution chromosome analysis was performed on peripheral lymphocytes (12).

\section{RESULTS}

Lipid and apolipoprotein profiles are illustrated in Figures 3 to 5. Total plasma cholesterol (Figure 3 ) was at the extremely high level of $37 \mathrm{mmol} / \mathrm{L}$ at age eight years. The patient was lost to follow-up between ages eight and 11 years. At age 12 years the plasma total cholesterol level was $19 \mathrm{mmol} / \mathrm{L}$, well above the upper normal level of 4.9 $\mathrm{mmol} / \mathrm{L}$. The lipoproteins that comprise the total plasma cholesterol are illustrated in Figure 4. Low density lipoprotein cholesterol (LDL-C), the majority of the total cholesterol, was well above the upper normal level of $3.18 \mathrm{mmol} / \mathrm{L}$ until age 14 years. High density lipoprotein cholesterol (HDL-C) initially was below normal levels but rose steadily to above the normal range $(0.88$ to $1.53 \mathrm{mmol} / \mathrm{L})$ until age 14 years. Lp-X, a low density precursor lipoprotein, was present in plasma and gradually declined. ApoB (normal 0.67 to $1.17 \mathrm{~g} / \mathrm{L}$ ) declined in parallel with LDL-C and rose when LDL-C increased at 15.3 years (Figure 5). Apoprotein A-I (normal 1.04 to $1.56 \mathrm{~g} / \mathrm{L}$ ) shows a steady rise with a concomitant rise in HDL-C (Figure 5). Total bilirubin, ALT and GGT are illustrated in Figure 6. They were all well above the normal range, with only slight improvement after age 12 years.
The GGT levels were compatible with an obstructive pattern as were bilirubin levels, which fluctuated between 39 and $85 \mu \mathrm{M} / \mathrm{L}$.

Figure 2 illustrates the presence of xanthomas on the patient's right ear and their resolution from ages 12 to 15 years. The resolution occurred gradually over the course of a number of months starting at 12.2 years of age. Overall, the patient had clinical resolution of xanthomas from age 12 to 13 years with a concomitant decline in total plasma cholesterol, LDL-C and associated apoprotein B. This was associated with a slight increase in HDL-C and the associated apoprotein A-I. 


\section{DISCUSSION}

Alagille syndrome is an autosomal dominant disorder with features of chronic cholestasis due to paucity of intrahepatic biliary ducts (91\%), characteristic facies (95\%), peripheral pulmonary stenosis (85\%), posterior embryotoxon (prominence of Schwalbe's line $88 \%$ ) and skeletal abnormalities $(87 \%)$ including butterfly-like vertebral arch defects or lack of increase in the interpedicular distance of the lumbar spine and short distal phalanges $(1,13)$. A deletion of chromosome 20 (p11.2, p12.3) has been detected in some individuals with Alagille syndrome (14-18), most of whom show evidence of developmental delay and dysmorphic features suggestive of a contiguous gene syndrome. Much variability has been noted in families with evidence of 'anticipation' which is the increased severity in subsequent generations $(14,19)$.

\section{REFERENCES}

1. Alagille D, Odievre M, Gautier M. Hepatic ductular hypoplasia associated with characteristic facies, vertebral malformations, retarded physical, mental, and sexual development, and cardiac murmur. J Pediatr 1975;86:63-71.

2. Alagille D, Estrada A, Hadchouel M, Gautier M, Odievre M, Dommergues JP. Syndromic paucity of interlobular bile ducts (Alagille syndrome or arteriohepatic dysplasia): Review of 80 cases. J Pediatr 1987;110:195-200.

3. Blomhoff JP, Home R, Ostrem T. Plasma cholesterol esterification and plasma lipoproteins in bile duct ligated dogs. Scand J Gastroenterol 1978;13:693-702.

4. Manzato E, Fellin R, Baggio C, Walch S, Newbech W, Seidel D. Formation of lipoprotein-X: Its relation to bile compounds. J Clin Invest 1976;57:1248-59.

5. Patsch JR, Kirk CA, Gotto AM, Morrisett JD. Isolation, chemical characterization and biophysical properties of three different abnormal lipoproteins LP-X1, LP-X2, LP-X3.

J Biol Chem 1977;232:211-320.

6. Seidel D, Alanpovic P, Furman RH. A lipoprotein characterizing obstructive jaundice. I. Method for quantitation, separation, and identification of lipoproteins in jaundiced subjects. J Clin Invest 1969;48:1211-23.

7. Burnstein M, Scholnick HR, Morfin R. Rapid method for the isolation of lipoproteins from human serum by precipitation with polyanions. J Lipid Res 1970;11:583-95.
The patient had the characteristic facies, peripheral pulmonary stenosis and chronic cholestasis due to paucity of intrahepatic biliary ducts. He had an incomplete form with three of the five features of Alagille syndrome, as is seen in $12 \%$ of patients (2). His karyotype is normal and his parents had no evidence of Alagille syndrome; therefore he may represent either a new mutation or nonpenetrance in one of his parents.

Intrahepatic cholestasis leads to elevation in liver enzymes and cholesterol. The lipoprotein and lipid profile of our patient was analyzed and showed remarkably high levels of cholesterol, the chief component of which was LDL-C with only low levels of HDL and Lp-X. Cholesterol levels and xanthomas have been shown to improve spontaneously in some cases of Alagille syndrome despite continued cholestasis with elevated bile acid (20-23).

8. Mancini G, Carbonara AO, Heremans JF. Immunochemical quantitation of antigens by single radial immunodiffusion. Immunochemistry 1965;2:235-54.

9. Panteghini M, Malchiodi A, Bonora R. A simple method for quantitative determination of lipoprotein-X (Lp-X) in human serum. Clin Chem Acta 1985;151:187-92.

10. Skipski VP, Goad JJ, Barclay M, Reggio RB. Quantitative analysis of simple lipid classes by thin layer chromatography. Biochem Biophys Acta 1968;152:10-9.

11. Bartlett GR. Phosphorus assay in column chromatography. J Biol Chem 1959;234:466-8.

12. Rooney DE, Czepulkowski BH. Tissue culture methods in human cytogenetics. In: Rooney DE, ed. Human Cytogenetics: A Practical Approach. Washington: Oxford, IRL Press, 1986:1-36.

13. Rosenfield NS, Kelley MJ, Jensen PS, Cotlier E, Rosenfield AT, Reley CA. Arteriohepatic dysplasia: Radiologic features of a new syndrome. Am J Roentgenol 1980;135:1217-23.

14. Anad F, Burn J, Matthews D, et al. Alagille syndrome and deletion of 20p. J Med Genet 1990;27:729-37.

15. Byrne JLB, Harrod MJE, Friedman JM, Howard-Peebles P. Del(20p) with manifestations of arteriohepatic dysplasia. Am J Med Genet 1986;24:673-8.

16. Legius F, Fryns JP, Eyskens B, et al. Alagille syndrome (arteriohepatic dysplasia) and del 20(p11.2). Am J Med Genet 1990;35:532-5.

17. Schnittger S, Hofers C, Heidemann P,
Previous reports have also demonstrated cholestyramine to be efficacious in the treatment of elevated plasma lipid levels in Alagille syndrome $(24,25)$. Our patient, however, began to show some improvement before initiation of drug or dietary measures. These reports have been of a milder nature with little information on lipoprotein classes. Our patient's total cholesterol LDL-C and Lp-X cholesterol levels and xanthoma improved after age 12 years despite continued cholestasis. He was started on a high soluble fibre diet and cholestyramine which may have influenced the decline in his cholesterol levels. This case illustrates the extraordinarily high levels of cholesterol and massive xanthomatosis that can be seen in individuals with Alagille syndrome.

Beermann F, Hansmann I. Molecular and cytogenetic analysis of an interstitial 20p deletion associated with syndromic intrahepatic ductular hypoplasia (Alagille syndrome).

Hum Genet 1989;83:239-44.

18. Zhang F, Deleuze J, Aurias A, et al. Interstitial deletion of the short arm of chromosome 20 in arteriohepatic dysplasia (Alagille syndrome). J Pediatr 1990;116:73-7.

19. Shulman SA, Hyams JS, Gunta R, Greenstein RM, Cassidy SB. Arteriohepatic dysplasia (Alagille syndrome): Extreme variability among affected family members. Am J Med Gen 1984;19:325-32.

20. Mueller RF, Pagon RA, Pepin MG, et al. Arteriohepatic dysplasia: phenotypic features and family studies. Clin Genet 1984;25:323-31.

21. Mueller DF. The Alagille syndrome (arteriohepatic dysplasia). J Med Gen 1987;24:621-6.

22. Henriksen NT, Drablos PA, Aagenaes O. Cholestatic jaundice in infancy. The importance of familial and genetic factors in aetiology and prognosis. Arch Dis Child 1981;56:622-7.

23. Weston CFM, Burton JL. Xanthomas in the Watson-Alagille syndrome. J Am Acad Dermatol 1987;16:117-21.

24. Branski D, Lebenthal E, Hatch TF, et al. Intrahepatic cholestasis for 15 years without cirrhosis. J Clin Gastroenterol 1980;2:252-7.

25. Flick AL. Arteriohepatic dysplasia: a 16 year follow up during treatment with cholestyramine. West J Med 1982;136:62-5. 


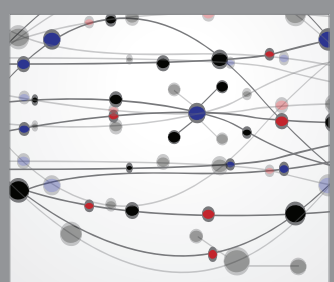

The Scientific World Journal
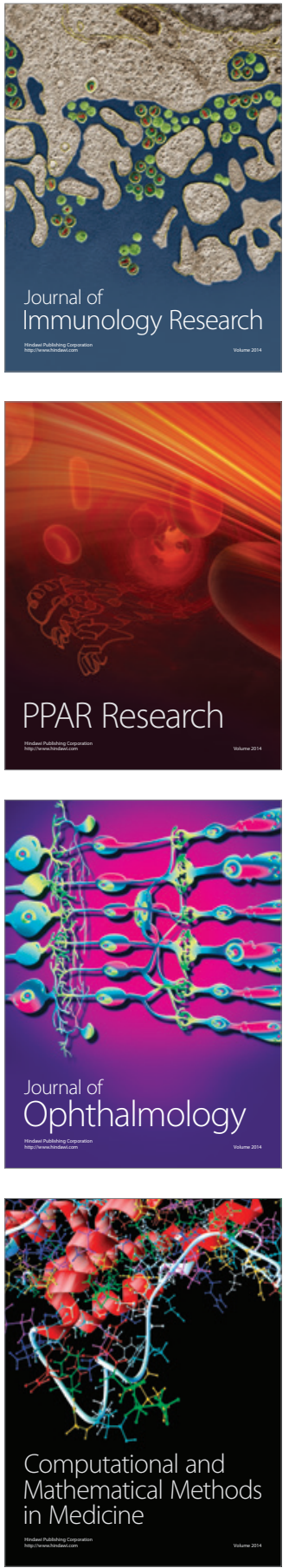

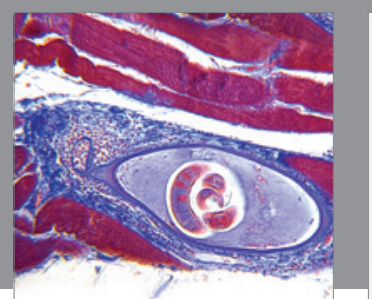

Gastroenterology Research and Practice

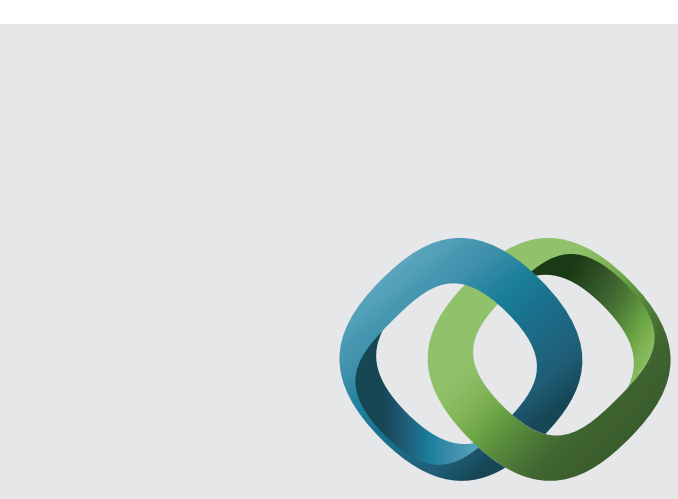

\section{Hindawi}

Submit your manuscripts at

http://www.hindawi.com
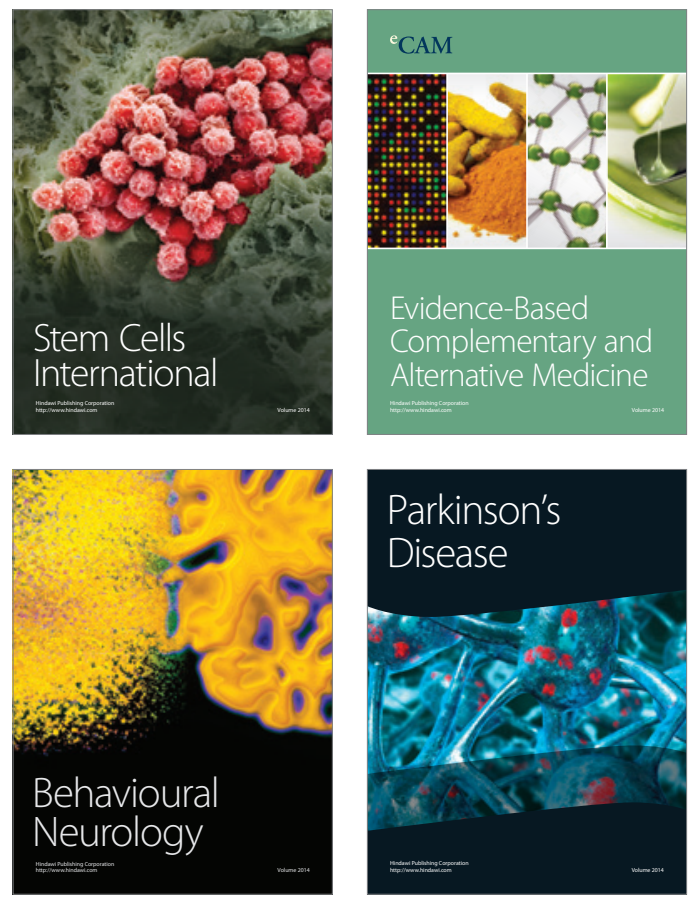
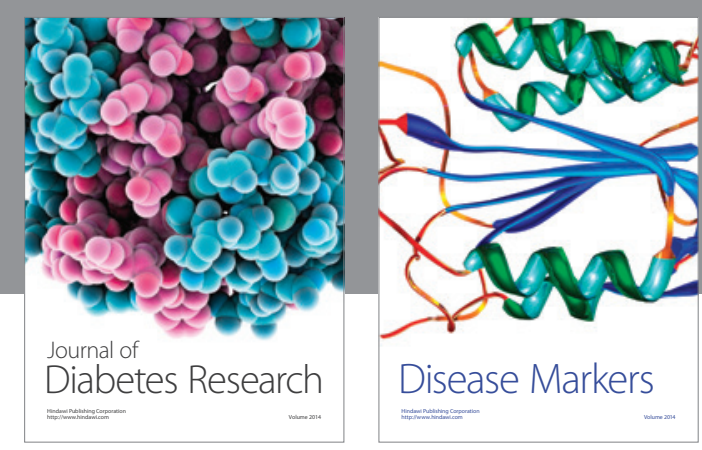

Disease Markers
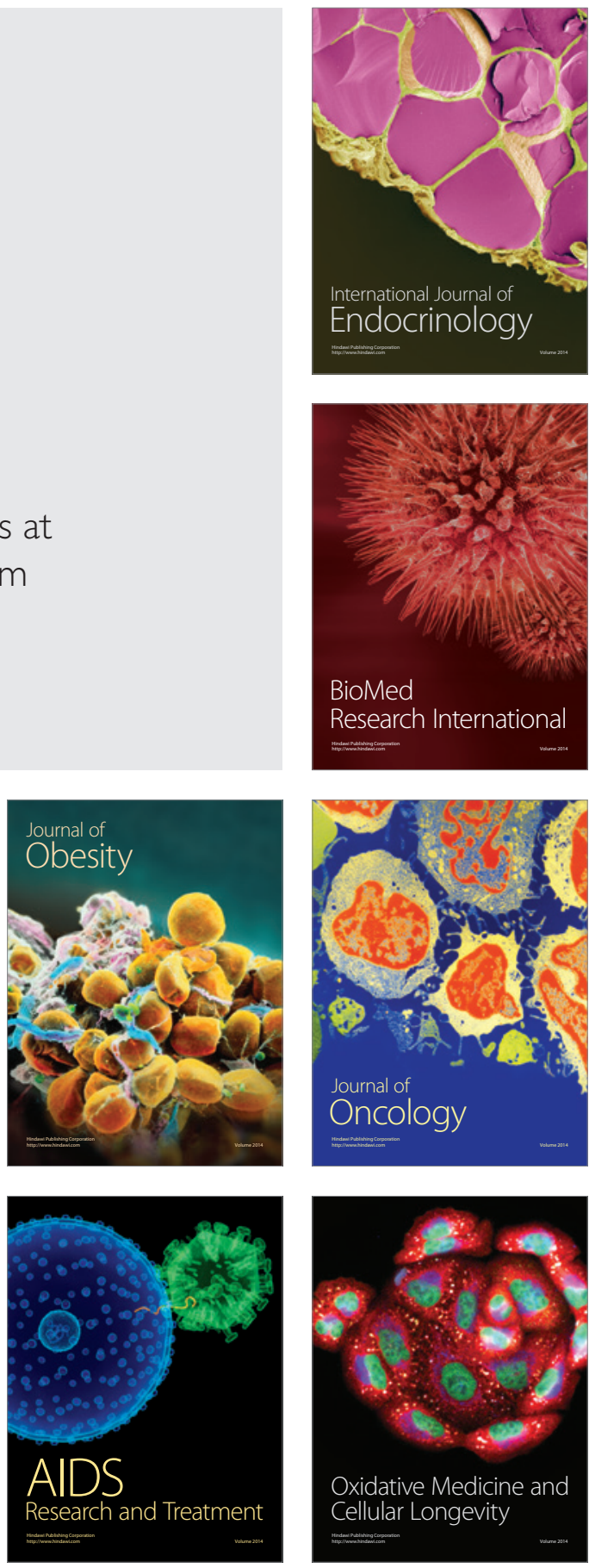